\title{
Pääkirjoitus: Suomen poliittinen talous vuonna 2020
}

Ville-Pekka Sorsa, päätoimittaja \& tutkimusjohtaja, valtiotieteellinen tiedekunta, Helsingin yliopisto

Poliittinen talous -lehden toimitus siirtyy vuoden 2021 alussa uusiin osaaviin käsiin. Lehdestä tulee toimituksen vaihdoksen myötä entistä monipuolisempi ja aktiivisempi julkaisufoorumi, joka tulee vahvistamaan tutkimusalan pitkäaikaista kehittämistyötä Suomessa. Kokemukseni perusteella julkaisutoiminta kotimaisilla kielillä on parhaimmillaan erittäin motivoivaa, laadukasta ja kannattavaa. On ollut etuoikeus seurata prosessia, jossa luovien tutkijoiden, ansiokkaiden tutkimusideoiden ja laatua varmistavien vertaisarvioijien välinen dialogi johtaa korkeatasoisten tieteellisten artikkeleiden julkaisemiseen. Kirjoittajien, vertaisarvioijien ja lukijoiden palaute artikkeleiden ja toimitusprosessin laatua koskien on ollut mieltäylentävää.

Useissa kansainvälisissä tieteellisissä lehdissä on ollut tapana, että väistyvä pidempiaikainen päätoimittaja päättää kautensa jonkinlaiseen tutkimusalaa edistävään "perintöön", kuten katsaukseen koskien lehden historiaa tai tutkimusalan senhetkistä kehityskaarta. Olen aiemmissa pääkirjoituksissa käsitellyt eräitä tutkimusalaan ja julkaisemiseen liittyviä pidempiaikaisempia kysymyksiä, kuten tieteellisten artikkeleiden luonnetta (Sorsa 2019) tai tutkimustiedon ja päätöksenteon suhteita (Sorsa 2017). Houkutus kirjoittaa näitä ajankohtaisemmista asioista oli liian suuri ohitettavaksi. Vuosi 2020 on ollut COVID-19-kriisin johdosta monella tapaa poikkeuksellinen ja tarve eri tieteenalojen aikalaisanalyyseille suurta.

Tämän artikkelin tarkoituksena on lyhyesti ilmaistuna muodostaa kokonaiskuva Suomen poliittisesta taloudesta vuonna 2020. Miksi tämä aihe? Yleisesti voidaan sanoa, että valtiotason poliittinen talous on yksi poliittisen talouden tutkimusalan hedelmällisimmistä tutkimuskohteista, koska se nivoo yhteen hyvin kattavasti erilaisia tarkastelun kohteita. Kokonaiskuvan muodostaminen valtiotasosta antaa esimerkin, jonka kautta voidaan hahmottaa luontevasti 
koko tutkimusalan luonnetta ja nykytilaa. Suomen poliittinen talous on jo sellaisenaan läheinen tutkimuskohde kotimaisia kieliä hallitseville tutkijoille. Valtiotason merkitys tutkimuskohteena on kuitenkin myös korostunut COVID-19-kriisin myötä. Kriisi nosti esiin keskeisiä eroja eri maiden poliittis-taloudellisten instituutioiden joustavuudessa ja toimintakyvyssä epävarmoissa olosuhteissa. Valtiotason poliittisen talouden pohdinta on hyvin ajankohtaista tilanteessa, jossa valtiotoimijoiden ja instituutioiden merkityksestä on saatu kouriintuntuva muistutus.

Toinen syy on siinä, että kokonaiskuvan muodostaminen on mahdollista kiitos tutkimusalan pitkäjänteisen edistämisen. Lehden ja sen julkaisijan eli Poliittisen talouden tutkimuksen seuran perustamisen aikoihin eli vuonna 2013 kokonaiskuvan muodostaminen olisi ollut vielä varsin hankalaa. Suomen poliittisen talouden eri osa-alueiden empiirinen tutkimus on lisääntynyt vajaan vuosikymmenen aikana siinä määrin, että jonkinasteinen kokonaiskuva voidaan nyt jo muodostaa. Merkittävin syy aiheen valinnalle onkin lopulta empiirinen: Suomen poliittisessa taloudessa on edellä kuvatun tutkimustiedon perusteella tapahtunut merkittäviä laadullisia muutoksia viimeisen vuosikymmenen aikana.

Artikkelia tulee lukea narratiiviseen kirjallisuuskatsaukseen perustuvana tulkitsevana esseenä ja aikalaisanalyyttisena keskustelunavauksena. Se ei ole varsinaisen katsausartikkeli, koska se ei perustu (eikä aiheen laajuuden takia ehkä edes voisi perustua) systemaattiseen kirjallisuuskatsaukseen. Artikkelia tulee lukea tutkimuksen tai ehkä oikeammin tutkimusohjelman lähtölaukauksena, jossa käsitteellistetään ja asemoidaan valtiotason poliittisen talouden tutkimusta, eritellään relevantteja tutkimuskohteita tulevia systemaattisia kirjallisuuskatsauksia ja empiiristä jatkotutkimusta varten sekä nostetaan jatkotutkimukselle eritasoisia hypoteeseja testattavaksi ja tulkintoja kritisoitavaksi.

Käsitteellistän artikkelissa ensin valtiotason poliittisen talouden tutkimusta ja pohdin Suomen poliittisen talouden perustojen viimeaikaisia muutoksia. Nostan tämän jälkeen esiin viimeaikaista tutkimusta Suomen poliittisen talouden keskeisistä instituutioista. Arvioin artikkelin lopuksi näiden löydöksien muodostamaa kokonaiskuvaa sekä yleisesti että erityisemmin COVID-19-kriisiin suhteuttaen. 


\section{Valtiollinen poliittinen talous tutkimuskohteena}

Aloitetaan peruskysymyksestä: mitä on poliittinen talous? Vastauksia kysymykseen on suunnilleen yhtä monta kuin tutkimusalalla on teoriaperinteitä ja koulukuntia, minkä vuoksi määritelmätyyppejä on syytä eritellä yleisemmällä tasolla.

Poliittinen talous voidaan määritellä esimerkiksi sen kautta, millaisia empiirisiä tutkimuskohteita tutkijat tarkastelevat tutkiessaan "poliittista taloutta". Poliittisen talouden tutkimus voidaan laajimmassa mielessä ymmärtää klassisen poliittisen taloustieteen mukaisesti yleisenä yhteiskuntatieteenä, joka pyrkii käsittelemään koko ihmiskunnan organisoitumista, toimintaa ja elämän uusintamista ilman lähtökohtaista jakoa tätä koskeviin näkökulmiin (ja tieteenaloihin), kuten vallankäyttöön ja kontingensseihin (politiikan tutkimus), sosiaalisiin suhteisiin ja aikaa kestäviin rakenteisiin (sosiologiaan) tai niukkuuteen ja laskelmointiin (taloustiede) (Sorsa 2019a).

Suppeammassa mielessä poliittinen talous voidaan ymmärtää spesifinä ja rajattuna tutkimuskohteena, jonka luonne ja laajuus riippuu näkökulmasta eli käytännössä "poliittisen" ja "talouden" määritelmistä. "Poliittisen” ja "talouden" näkökulmien laajuus vaihtelee erittäin paljon lähestymistavasta riippuen. Otetaan esimerkiksi alan oppikirjat. Politiikan tutkimuksen parista nouseva poliittisen talouden tutkimus, jossa poliittisuus ymmärretään suhteellisen laajasti, käsittelee tyypillisesti niitä tapoja, joilla erilaiset valtakamppailut, ideat ja muut historialliset prosessit ("poliittinen") vaikuttavat tavaroiden ja palveluiden tuotantoon, vaihtoon ja jakamiseen ("talous") eri yhteiskuntien jäsenten parissa (esim. Stilwell 2011). Taloustieteen käsitys poliittisesta taloudesta (esim. Phelps 1985) taas käsittelee tyypillisesti laskelmoivaa käyttäytymistä ja optimointia ("talous") spesifisti julkisen sektorin sääntelyä, rahoittamista ja muuta hallintakeinoja koskevassa päätöksenteossa ("poliittinen").

Poliittista taloutta voidaan määritellä myös sen mukaan, millaisia tutkimusongelmia tutkimusalalla ratkotaan. Merkittävä osa kysymyksenasetteluista ovat empiirisiä. Vertailevan poliittisen talouden (comparative political economy) tutkijat vertailevat empiirisesti erilaisia aktuaalisia poliittis-taloudellisia järjestelmiä ja instituutioita (esim. Nölke 2016). Poliittis-taloudellisten järjestysten, konstellaatioiden ja vuorovaikutusten teoreettisia, materiaalisia, vallankäytöllisiä ja muita perustoja tutkitaan taas ennen kaikkea globaalin poliittisen 
talouden tutkimuksen (global political economy) piirissä (esim. Kotilainen ja Patomäki 2020). Monia näistä teemoista tutkitaan myös spesifimmin kansainvälisen suhteiden teoriaan nojaavan kansainvälisen poliittisen talouden tutkimuksen (international political economy) parissa (ks. Cohen 2017).

Poliittisen talouden tutkimuksen piirissä tehdään runsaasti myös normatiivista ja teoreettista tutkimusta. Teoreettisen poliittisen talouden tutkimuksessa (theoretical political economy) kuvaillaan, tulkitaan, kritisoidaan ja toisinaan pyritään myös järjestelmään taloutta valittujen teoreettisten käsitejärjestelmien ja normatiivisten periaatteiden kautta. Normatiivisen poliittisen talouden tutkimuksen (normative political economy) tutkimushaarassa tutkitaan tarkemmin talouspolitiikan ja taloudellisten instituutioiden arvioinnissa käytettyjä kriteereitä, eettisiä periaatteita ja filosofioita (esim. Levine 2014). Kriittisen poliittisen talouden tutkimuksen (critical political economy) tutkimushaarassa taas keskeiset tutkimusongelmat koskevat talouden teorioiden ja käytäntöjen sisäisiä ja välisiä ristiriitoja sekä niiden ylittämistä (esim. Browning ja Kilmister 2006). Tarvetta käydä normatiivista ja filosofista keskustelua voidaan pitää osoituksena niin tutkimuskohteen perustavanlaatuisesta kiistanalaisuudesta kuin tutkijoiden merkittävästä vaikutuksesta tutkimuskohteensa toimintaan (ks. Sorsa 2013). Toisinaan asian x poliittisen talouden tarkasteluun sisällytetäänkin myös asian x tutkimus.

Tämän artikkelin käsitys poliittisesta taloudesta on jossain suppean ja laajan käsityksen puolivälissä sekä empiiriseen tutkimukseen pääasiallisesti nojaava. Se perustuu eräänlaiseen "keskimatkan teoriaan" (ks. Jackson ja Deeg 2019), joka ponnistaa empiriasta eli tutkittavista ilmiöistä ja tutkimuskohteen erityisistä laadullisista ominaisuuksista, mutta sisältää myös löydöksien laajemman teoreettisen ja normatiivisen arvioinnin. Määrittelen poliittisen talouden Moscoa (2009) seuraten valtasuhteiksi, jotka keskenään konstituoivat erilaisten resurssien tuotannon, jaon ja kulutuksen ilmiön. Artikkelin tavoitteena on koostaa empiirisen tutkimuksen pohjalta kokonaiskuva maantieteellisesti rajatusta valtasuhteiden kokonaisuudesta, joka voi näyttäytyä eri näkökulmista niin yksikkönä, toimijana kuin toimintaympäristönäkin. Nostan esiin myös tutkimustietoa valtasuhteiden muuttuvista perustoista, jotka potentiaalisesti selittävät poliittisen talouden muutoksia - varsinaiseen selittämiseen vaadittaisiin toki yhden artikkelin sijaan kokonainen tutkimusohjelma. 
Tutkimuskohteen erityisenä ominaisuutena on rakenteeltaan kapitalistinen raha- ja markkinatalous. Analyysi kohdistuu siksi tietynlaisiin institutionalisoituihin valtasuhteisiin: erilaisten yritysten ja markkinoiden toimintaan liittyviin suhteisiin sekä rahallisiin ja pakottaviin vallankäytön keinoihin. Tutkimuskohteen ominaisuuksien jäsentelyn ja laajemman tulkinnan perustana toimii vertailevan poliittisen talouden tutkimuksen perinteessä suosittu vertailevan kapitalismin (comparative capitalism) lähestymistapa (Nölke 2016; 2019). Pyrin käytettävissä olevan tiedon valossa tulkitsemaan muutoksien merkityksiä erityisesti institutionaalisten komplementaarisuuksien eli talouden eri instituutioiden välisen yhteensopivuuden ja -toimivuuden näkökulmasta (Witt ja Jackson 2016). Näkökulma on keskeinen muun muassa talouden hallittavuuden, kansallisen kilpailukyvyn ja yritystoiminnan helppouden arvioinnille.

\section{Suomen poliittisen talouden perustojen muutos}

Poliittisen talouden tutkimuksessa on käsitelty kolmea yleistä poliittisen talouden perustaa, joiden avulla muutosta voidaan selittää: intressit, instituutiot ja ideat (Hay 2004). Nämä kolme perustaa eivät ole toisistaan erillisiä, vaan ne tulisi nähdä ennemminkin tapana eritellä valtasuhteita tuottavia ja muokkaavia vaikuttimia (suomeksi ks. esim. Sorsa ja Eskelinen 2018). Intressit viittaavat yksittäisten toimijoiden välisiin suhteisiin ja toimintaa koskeviin motiiveihin ja kiinnostukseen, kuten toiminnasta saatavaan hyötyyn, etuun, mielihyvään, tunnustukseen tai muuhun hyvään (Woolgar 1981). Instituutiot viittaavat vakiintuneisiin ja aikaa kestäviin sosiaalisiin käytäntöihin ja rakenteisiin, kuten sopimuksiin, lakeihin, normeihin ja käsikirjoituksiin, jotka mahdollistavat, rajoittavat ja sääntelevät ihmisten ja organisaatioiden toimintaa (Gronow 2008). Ideat viittaavat eriteltävissä oleviin normatiivisiin tai kognitiivisiin ajatusrakennelmiin, jotka kertovat toimijoille, mikä on mahdollista ja toivottavaa, ja jotka voivat poliittis-taloudellisessa päätöksenteossa nousta toimenpiteitä määrääviksi ohjelmiksi tai/ja toimenpiteitä muille päätöksentekijöille ja yleisöille legitimoiviksi kehyksiksi (Campbell 1998).

Vertailevan kapitalismin tutkimuksessa intressien tutkimus kohdistuu pääasiallisesti liiketoimintajärjestelmien sisältämiin liiketoimintaintresseihin ja niihin liittyviin laajempiin valtaintresseihin (esim. Nölke 2016). 2000-luvun 
taitteessa Suomen liiketoimintajärjestelmä oli jakaantunut kansainvälistymisen myötä kahteen intressinapaan: kansainvälisiin vientiyrityksiin ja kotimarkkinoista riippuvaisiin yrityksiin (Skurnik 2005). 2010-luvulle tultaessa intressit olivat jossain määrin kolminapaistuneet (ks. Sorsa 2014b). Nokian "romahduksen" jälkeen kansainvälisillä markkinoilla operoivat yritykset eivät enää jakaneet samoja menestyksen lähteitä. Esimerkiksi metsä- ja metalliteollisuuden avaintekijät ( $\mathrm{mm}$. toimitusketjujen vakaus, alhainen verotus, energiaratkaisut) ovat huomattavan erilaisia kuin luovien alojen tai kansainvälisten bisnespalveluiden vastaavat ( $\mathrm{mm}$. sosiaaliset investoinnit, koulutus, innovaatiokeskittymät). Johdonmukainen politiikka muuttuu haastavaksi, jos yhden navan intressien palveleminen johtaa yhden sijaan kahden navan intressien vastaiseen toimintaan.

Aihetta eksplisiittisesti tarkastelevan tutkimuksen vähäisyyden johdosta on hankalaa arvioida, onko 2020-luvulle tultaessa moninapaistuminen jatkunut. On kuitenkin selvää, että liiketoimintajärjestelmän rakenne on muuttunut. Tilastojen nojalla Suomen talouden rakenne muuttui 2010-luvun aikana myös entistä palveluvetoisemmaksi - jo noin $70 \%$ bruttoarvonlisäyksestä tulee palveluista ja yksityiset palvelut vastaavat yli puolesta Suomen bruttokansantuotteesta. Suomessa tuotettavien palveluiden merkitys on lisääntynyt ja teollisuuden merkitys vastaavasti vähentynyt. On myös selvää, että suomalaisten monikansallisten yritysten rooli arvonlisäyksessä on vähentynyt merkittävästi: suomalainen arvonlisäys tuotetaan entistä useammin pienten yritysten toimesta, asettuu pitkien ja "disaggregoitujen" (Morgan 2014) ylikansallisten arvoketjujen periferiseen asemaan sekä realisoituu laajamittaisesti ulkomailla. Toisaalta Suomessa on edelleen merkittäviä kansainvälisiä arvo- ja omistusketjuja koordinoivia toimijoita (Suomesta ks. Finér ja Ylönen 2017).

Näiden tekijöiden valossa voi esittää jatkotutkimukselle testattavaksi hypoteesin, että liiketoimintajärjestelmän intressit ovat mahdollisesti jälleen kaksinapaistuneet. Nyt vastakkain ovat kuitenkin 1) Suomessa toimivat, osaksi kotimaisesta kysynnästä riippuvaiset ja osaksi laajoissa kansainvälisissä arvoketjuissa operoivat lukuisat palvelualan yritykset sekä 2) harvat ylikansallisia arvoketjuja koordinoivat suuryritykset, joilla on merkittävää tuotannollista toimintaa muiden maiden ohella myös Suomessa. Siinä missä edellisille esimerkiksi korkean palkkatason tuoma palvelukysyntä, osaavaa työvoimaa houkuttelevat hyvät elinolosuhteet ja nämä takaavat sosiaaliset investoinnit, 
korkea koulutustaso ja pienten yritysten yhteistyötä edistävä innovaatiojärjestelmä ovat erittäin keskeisiä, näyttävät ne jälkimmäiselle useimmiten joko irrelevanteilta tekijöiltä tai kustannuseriltä. Edellinen intressikeskittymä on Suomen talouden kannalta painoarvoltaan moninkertainen jälkimmäiseen nähden, mutta vain jälkimmäinen voi päättää suhteellisen keskitetysti vaihtaa maisemaa. Kaikkien intressien palveleminen ja sovitteleminen valtiotasolla on muuttunut haastavaksi.

Materiaalisten liiketoimintaintressien ohella myös yritysten valtaintressit näyttävät muuttuneen. Yritysten etujärjestöjen kentässä on tapahtunut merkittäviä siirtymiä kohti toimialakohtaista tai kapeampaa yritysrypäskohtaista vaikuttamistoimintaa. Syynä tähän on tiivistetysti se, että edustuksellinen toiminta nähdään intressiristiriitojen takia aiempaa hankalammaksi samalla, kun yritykset saavat ajettua omia intressejään yhteistyöorganisaatioita tehokkaammin läpi muilla keinoin, kuten esimerkiksi vaikuttajaviestinnän ja verkostovaikuttamisen avulla (Aitonurmi 2019). Voidaankin siis esittää, että valtaintressien kaksinapaistumisen sijaan on mahdollisesti siirrytty "navattomaan" eli sellaiseen tilanteeseen, jossa yritysten intressit eivät muodosta selkeitä ja pidempiaikaisia blokkeja, vaan motivoivat ennemmin tapauskohtaista, episodista ja muodoltaan vaihtelevaa vaikuttamistoimintaa.

Instituutioiden osalta vertailevan kapitalismin tutkimuksessa tutkitaan joko valtiollisen kapitalismin variaation konstituoivia instituutioita - joita tarkastelen seuraavassa luvussa - tai näihin vaikuttavia laajempia globaalin ja kansainvälisen toimintaympäristön instituutioita (Nölke 2019), joita seuraavaksi lyhyesti pohdin. Suomen talous on vahvasti integroitunut pohjoismaisiin markkinoihin yritysten pohjoismaistumisen johdosta, minkä lisäksi Suomen ja Viron työmarkkinoiden välillä vallitsee monenlaisia dynamiikkoja. Suomi noudattaa edelleen tuhansia kahdenvälisiä ja monenvälisiä sopimuksia, jotka ohjaavat ja rajoittavat valtion toimintaa periaatteellisesti. Lisäksi monet epämuodolliset normit, kuten kansainväliset työnjaot tai auktoriteettiasemat, vaikuttavat valtion toimintamahdollisuuksiin. Poliittisen talouden kannalta merkittävimmät tekijät ovat Euroopan unionin ja eurojärjestelmän jäsenyys, joiden kautta Suomi on delegoinut merkittävän osan vallankäyttöä - erityisesti kauppapolitiikan, markkinoiden sääntelypolitiikan ja rahapolitiikan kansainvälisille elimille. 
Tiiviisti ilmaistuna Suomen institutionaalinen ympäristö on suhteessa 2010-luvun pysynyt muodollisesti pitkälti ennallaan, mutta itse instituutioiden toiminta uusissa olosuhteissa ja sitä kautta niiden ylläpito horjuvat merkittävästi. Vuosikymmenen alun eurokriisi ja euromaiden reaktiot siihen osoittivat, ettei Euroopan integraatioprojektin tämänhetkinen institutionaalinen rakenne pysty sovittamaan yhteen erilaisia kapitalismeja tasapuolisesti (Johnston ja Regan 2018). Epätasapainot kotimarkkinoista riippuvaisemman etelän ja kansainvälisestä kysynnästä riippuvaisemman pohjoisen välillä ovat hyödyttäneet ensisijaisesti jälkimmäisiä. Tilannetta ylläpitävä talouspoliittinen kuri ja muut eurokriisin aikaiset toimenpiteet ovat nostaneet esiin huolen Eurooppa-projektin demokraattisen legitimiteetin heikentymisestä (esim. Tuominen 2015; 2019). Ison-Britannian ero EU:sta on herättänyt kysymyksiä Eurooppa-projektin yleisestä poliittisesta kestävyydestä.

Laajemmin tarkasteltuna voidaan esittää hypoteesi, että kansainvälisen poliittisen talouden instituutiot on päästetty pitkälti "ajelehtimaan" (drift) eli niitä ei ole uudistettu riittävästi vastaamaan ajan tarpeita. Ajelehtimisen johdosta valtioiden merkitys toimintakykyisinä hallinnan yksiköinä on kasvanut, kun taas niiden mahdollisuudet välttää ja keinot lieventää taloudellisia riskejä ovat heikentyneet. Esimerkiksi kansainvälisten poliittisten instituutioiden kyvyttömyys ratkoa ilmastonmuutoksen ongelmia on ajanut maapallon tilanteeseen, jossa kaikkein suurimpien taloudellisten riskien realisoituminen näyttää jo lähes varmalta, mutta jossa näitä riskejä ei aina edes huomioida kansainvälisessä päätöksenteossa, vaan riskienhallinta jätetään valtioiden harteille. Talouden finansoituminen taas on kasvattanut taloussykleihin liittyviä systeemisiä riskejä, joiden hallintaan vastuutetut keskuspankit operoivat osittain kansallisesti määrittyvän toimintakykynsä rajoilla (Ronkainen ja Sorsa 2018).

Ideoiden osalta vertailevan kapitalismin tutkimus käsittelee sekä poliittisen ja taloudellisen pintatasolla vaikuttavia ideoita että yleisempiä asiantuntijaparadigmoja ja "kansan tuntemuksia" mediakehykset ja julkisen keskustelun kehykset mukaan lukien (Campbell 1998). Viime vuosina tutkimuksessa on korostettu myös ideoita päätöksentekoon kanavoivia ja valikoivia mekanismeja eli niin kutsuttuja tiedontuotannon regiimejä (Campbell ja Pedersen 2014). Käsittelen tässä yhteydessä vain varsinaisessa päätöksenteossa vaikuttavia ideoita ja tiedontuotannon regiimejä, sillä asiantuntijakeskustelussa 
ja julkisessa keskustelussa esiintyy liian laaja valikoima poliittis-taloudellisia ideoita käsiteltäväksi yhdessä artikkelissa.

2010-luvulle tultaessa kotimaista talouspoliittista päätöksentekoa hallitsivat pääasiallisesti kilpailukyvyn (Kantola ja Kananen 2013), kestävyysvajeen (Sorsa 2014a) ja kansallisen innovaatiojärjestelmän (Alaja ja Sorsa 2020) ideat. Kilpailukyvyn idean sisällössä tapahtui 2010-luvun aikana merkittävä muutos: investointiympäristön kansainvälistä houkuttelevuutta korostava laajemman "porterilaisen" kilpailukyvyn idea väistyi varhaisempaa juurta olevan suppeamman hintakilpailun idean tieltä Sipilän hallituksen myötä (Kaitila 2019). Kestävyysvajeen idean käyttö voimistui vuosikymmenen ensimmäisellä puoliskolla, jolloin sitä käytettiin muun muassa oikeuttamaan valtion harjoittamaa sanelupolitiikkaa työeläkeuudistuksen yhteydessä (Lindén 2016). Kestävyysvajeen idea on luultavasti pysynyt vahvana asiantuntijoiden parissa, mutta sen "argumentatiivinen voima" on todennäköisesti heikentynyt politiikassa. Kestävyysvajeen ideaa ensisijaisena politiikan kehyksenä ovat haastaneet muun muassa Rinteen ja Marinin hallitusten työllisyystavoitteet. Kansallisen innovaatiojärjestelmän idea on kadonnut lähes kokonaan kotimaisen politiikan parista (Alaja ja Sorsa 2020). Voidaankin sanoa, että Suomen poliittisen talouden ensisijainen ideapohja perustui koronakriisin alla varsin yksinkertaisille vientikilpailukyvyn ja työllistämisen ideoille.

Samaan aikaan ideoiden merkitys on todennäköisesti kasvanut tiedontuotannon regiimin muutoksen kautta. Suomen tiedontuotannon regiimi on historiallisesti huomattavan moninainen: eri politiikan lohkoilla vaikuttavat hyvin erilaiset ideoita, asiantuntijuutta ja päätöksentekoa yhdistävät organisaatiokentät. Poliittisen päätöksenteon viime vuosikymmenten yleistä kehitystä yhdistävät pysyvien elinten ja sitä kautta edustuksellisuuden vähentyminen (esim. komitealaitoksen poistaminen) sekä asiantuntijavetoisuuden lisääntyminen ( $\mathrm{mm}$. selvityshenkilöiden merkityksen nousu ja näyttöön perustuvan politiikan vaatimukset). Poliittisesta päätöksenteosta on tullut tiedon tuotannon ja käytön osalta episodisempaa ja valikoivampaa.

Suomen tiedontuotannon regiimiä luonnehti 2010-luvulle tultaessa ennen kaikkea taloustieteellisen tiedontuotannon nousu päätöksenteon ensisijaiseksi tiedoksi (Elomäki ym. 2020; Ylöstalo 2020a; 2020b; ks. myös Ylönen ym. 2020), "konsultokratian" eli tiedon hankinnan ja käsittelyn ulkoistaminen useilla eri mekanismeilla yleistyminen (Ylönen ja Kuusela 2019) sekä 
molempiin liittyen valtiovarainministeriölle (VM) annettu merkittävä asema regiimin useiden osa-alueiden koordinaattorina (Eskelinen ja Sorsa 2011). Anekdotaaliset esimerkit kertovat, että regiimissä tapahtui pieniä mutta merkittäviä muutoksia 2010-luvun aikana. Taloustieteellinen tieto tarjosi koronakriisin alla edelleen politiikan keskeisen ideapohjan, mutta tämä ideapohja vaikuttaa päätöksentekoon nyt eri kanavien kautta. Selvityshenkilöiden nousu valmisteluun ja esimerkiksi Talouspolitiikan arviointineuvoston perustaminen (v. 2014) ovat korostaneet taloustietelijöiden asemaa politiikan episodisessa valmistelussa ja arvioinnissa. Vaikka asiantuntijaideat esiintyvät harvoin varsinaisessa talouspoliittisessa puheessa (Lillqvist ym. 2020), on korkeassa asemassa olevilla taloustieteilijöillä erittäin merkittävä asema mediakehysten määrittäjänä (Harjuniemi 2020). Regiimistä on tullut 2010-luvun aikana entistä enemmän ulkoistettuun tiedontuotantoon nojaavaa, mutta myös entistä ohjatumpaa valtion tutkimuslaitosuudistuksen ja tiedettä ohjaavien rahoitusinstrumenttien yleistymisen myötä. VM:n asema regiimin yleisenä koordinaattorina on heikentynyt, kun koordinaatiovalta on siirtynyt entistä vahvemmin valtioneuvoston ylimmälle ja strategiatyön tasoille (Ihatsu 2020).

Hypoteesina voidaan esittää, että kotimainen tiedontuotannon regiimi on kokonaisuutena aiempaa selkeämmin sekä valtion ohjauksessa että asiantuntijuutta tietoisesti valikoiva. Kuten tietoon perustuvan politiikan paradigmassa saattaa odottaa, siirtyy politiikka tiedon tuotantoon ja asiantuntijoiden valikointiin (Sorsa 2017b). Päätöksenteon episodimaisuuden lisääntyminen ja asiantuntijavallan kasvaminen kasvattavat ideoiden merkitystä politiikkaa ja asiantuntijuutta yhteen keräävänä voimana.

\section{Suomen kapitalismin variaatio}

Vertailevan kapitalismin tutkimuksen ensisijainen tutkimuskohde on yritystoimintaan liittyvät instituutiot, jotka konstituoivat tuotannollisen toiminnan ohjauskeinot. Näiden instituutioiden väliset komplementaarisuudet määrittävät kyseisen toimintaympäristön transaktiokustannuksia, tuotannollista kilpailukykyä ja näiden kautta taloudellista suorituskykyä (Nölke ja Vliegethart 2009). Kapitalismin variaatioita voidaan eritellä niiden instituutioiden tuottamien koordinaatiomekanismien kautta. Alan varhainen tutkimus vertaili 
erityisesti sopimuksellisiin markkinasuhteisiin perustuvia joustavia liberaaleja markkinatalouksia ja eri toimijoiden väliseen neuvotteluun perustuen päätöksenteolla muutettavissa olevia koordinoituja markkinatalouksia (Hall ja Soskice 2001). Sittemmin tutkimuksessa on tunnistettu huomattava määrä erilaisia variaatioita ja koordinaatiotapoja (esim. Witt ja Jackson 2016).

Suomalaista kapitalismin variaatiota on ollut historiallisesti vaikeaa niputtaa muiden joukkoon. Sitä voidaan pitää hyvin omintakeisena, ellei jopa omana variaationaan (Oinas 2005). Perinteisesti Suomessa on esiintynyt monia neuvotellen koordinoitujen markkinatalouksien piirteitä, kuten yhteistyöhön perustuva innovaatiojärjestelmä sekä keskitetty ja sektorikohtainen työmarkkinapolitiikka. Näiden johdosta Suomi on usein myös luokiteltu koordinoiduksi markkinataloudeksi (esim. Hall ja Soskice 2001; Witt ym. 2018). Toisaalta EU-integraatio ja EMU-jäsenyys sekä monet markkinoiden sääntelyreformit ovat tuoneet Suomeen liberaalien markkinatalouksien markkinavetoisen koordinaation piirteitä (Moen ja Lilja 2005). Suomessa esiintyy historiallisesti myös monia niin sanottujen riippuvaisten markkinatalouksien piirteitä. Riippuvaiset markkinataloudet pyrkivät tarjoamaan kansainvälisten suuryritysten sisäisesti hallinnoimille ja usein ulkomaille voittoja vieville arvoketjuille mahdollisimman vakaat ja ennakoitavat olosuhteet (Nölke ja Vliegenthart 2009). Nämä piirteet näkyvät erityisesti metsäteollisuuden tapauksessa (ks. Oinas 2005). Samoja piirteitä oli nähtävissä myös Nokian menetysvuosina, jolloin osa kotimaisesta liiketoimintajärjestelmästä rakennettiin jopa suoraan Nokian arvoketjujen varaan (ks. Kristensen ja Lilja 2011).

Lyhyesti sanottuna Suomi on edustanut kapitalismin variaationa jonkinlaista epäselvää hybridiä. Se ei palaudu selkeästi mihinkään yhteen ideaalityyppiin joko riittävän monen osa-alueen osalta tai ainakaan riittävän pitkäaikaisesti edustaakseen yhtä tyyppiä tai edes selkeää hybridiä. Tämä voi myös olla yksi syy Suomen taloudelliseen menestykseen. Viime vuosina vertailevan kapitalismin tutkimuksessa on korostettu, että globaalisti menestyksekkäimmät eli radikaaleimpia innovaatioita ja korkeimpia arvonlisäyksiä tuottaneet taloudet ovat olleet hybridejä - joko koordinoituja markkinatalouksia tai useiden Aasian maiden kaltaisia valtiojohtoisia markkinatalouksia, joihin molempiin on tuotu niiden ydinelementtejä liiaksi häiritsemättömiä "hyödyllisiä rajoituksia" tuottavia liberaalien markkinatalouksien piirteitä (Witt ja Jackson 2016). 
Erilaisten instituutioiden keskinäisten suhteiden ja koordinaatiokapasiteetin analyysi vaatii kuitenkin instituutioiden tarkempaa laadullista analyysia (Jackson ja Deeg 2019). Taloudellisen koordinaation kannalta keskeisiä instituutioita on jaoteltu ja eritelty tutkimuksessa hyvin monilla eri tavoilla. Myös analyysin laajuus on vaihdellut. Vertailevan kapitalismin tutkimuksen kahdessa ensimmäisessä aallossa huomio keskittyi hyvin vahvasti valtioiden sisäisiin niin sanottuihin tarjontapuolen eli tuotannon kannalta keskeisiin instituutioihin, mutta kolmannessa aallossa huomiota on alettu kiinnittää myös kysyntään ja ylikansallisiin konstellaatioihin (Nölke 2016).

Keskityn tässä yhteydessä tilarajoitusten vuoksi pääasiallisesti yritystoimintaan liittyviin, suhteelliseen karkeasti eroteltuihin instituutioihin. Pyrin huomioimaan näiden osalta kuitenkin myös kysyntään sekä ylikansallisiin vaikutussuhteisiin ja kehityskulkuihin liittyviä seikkoja. Jaottelen pohdinnan neljään instituutioiden nippuun: 1) yritysten ohjausta määrittävät rahoitus ja yhtiöhallinto, 2) työn ohjausta määrittävät työmarkkinat ja työmarkkinapolitiikka, 3) tiedon ja osaamisen ohjausta määrittävä innovaatiojärjestelmä sekä 4) kokonaiskysyntää ja -tarjontaa ohjaava makrotaloudellinen regiimi.

Rahoitus ja yhtiöhallinto. Pidemmän aikavälin muutokset Suomen yhtiöhallinnossa ja rahoitusjärjestelmässä liittyvät koko liiketoimintajärjestelmän muutokseen. Pankkilainoihin perustuva rahoitusjärjestelmä, lainojen vakuuksiksi annettujen osakkeiden antama omistajavalta pankeille, pääomablokkeihin perustuva vallankäyttö yrityksissä ja kaksitasoisesti hallinnoitujen monialaisten yritysorganisaatioiden muodostamat markkinat olivat 2000-luvulle tultaessa väistyneet markkinapohjaisen rahoituksen ja osakkeenomistajien hallitsemien, yksitasoisesti hallinnoitujen ja erikoistuneiden yritysten tieltä (Tainio ja Lilja 2003). 2000-luvun ensimmäisen vuosikymmenen aikana yhtiöhallinnossa omaksuttiin pitkälti EU-tason ja muiden kansainvälisten trendien mukaisia yritysjohdon itsenäisyyttä ja osakkeenomistajien yhdenvertaista kohtelua vahvistavia piirteitä, joskin monia muita maita sitovammassa muodossa (Mähönen 2013). EU-jäsenyyden ja myöhemmin EMU-jäsenyyden myötä Suomi integroitui markkinavetoiseen eurooppalaiseen rahoitusjärjestelmään.

2010-luvun alun Suomen yhtiöhallintoa voidaan kutsua omistusvallan suhteiden osalta jokseenkin hajaantuneeksi. Kotimaisten yritysten omistus oli keskimäärin hajaantunutta, eikä suuremmissa yrityksissä ollut selkeitä enemmistöomistajia tai sellaisia ankkurisijoittajia, jotka yhdessä muodostaisivat 
enemmistöomistuksen (Jakobsson ja Korkeamäki 2015). Kotimaisten eläkerahastojen asema omistajaohjauksen koordinaattorina oli näissä olosuhteissa merkittävä (McCarthy ym. 2016). 2010-luvun kehitystä on tutkittu vielä vähänlaisesti. Talouden rakenteellisen muutoksen luonteen johdosta voidaan kuitenkin esittää hypoteesi, että 2010-luvun aikana kehitys on kulkenut kahteen suuntaan. Molemmat muutokset ovat kuitenkin luonteeltaan sellaisia, että päätösvalta yrityksissä on 2010-luvun alkua jonkin verran keskittyneempi johtajien käsiin. Yhtäältä pääoma on hajaantunut, koska Nokian kaltaisten suurten yritysten varassa integroitujen arvoketjujen merkitys on vähentynyt, ja kansainvälisissä arvoketjuissa operoivien pienempien, pääasiallisesti johtajiensa omistaman yritysten merkitys vastaavasti lisääntynyt. Suurten institutionaalisten sijoittajien kyky omistaa pieniä yhtiöitä on hyvin rajallinen. Toisaalta pääoma on keskittynyt, koska Suomessa toimivat suuremmat yritykset ovat nykyään entistä useammin joko pohjoismaisia yrityksiä tai kansainvälisten konsernien tytäryhtiöitä. Sijoittajat joutuvat vaikuttamaan toimintaan hyvin etäältä eli emoyhtiöiden kautta.

Vuosien 2008-2009 finanssikriisi koetteli Suomen rahoitusjärjestelmää vähänlaisesti verrattuna esimerkiksi ruotsalaispankkeihin. Kotimainen rahoitusjärjestelmä on yleisesti ottaen osoittautunut erittäin resilientiksi ja vakavaraiseksi. Suomen yritysrahoitusjärjestelmää voitiin kutsua jo 2010-luvun alussa huomattavan pluralistiseksi, kattavaksi ja koordinaation näkökulmasta hyvin markkinavetoiseksi. Vaikka pankkilainojen osuus yritysten rahoituksesta oli edelleen suuri, käyttivät yritykset myös lukuisia erilaisia rahoituslähteitä, kuten esimerkiksi osakeanteja, joukkovelkakirjoja, takaisinlainoja eläkerahastoista ja Finnveran rahoitusta (ks. tarkemmin Suomen Pankki 2015). Rahoituksen saatavuus ei ole ollut yrityksille merkittävin pullonkaula sitten 1990-luvun alun. 2010-luvulla enää lähinnä mikroyritykset ja kasvavat mutta edelleen pienet yritykset kärsivät rahoituksen rajallisesta saatavuudesta, joka johtui pääasiallisesti vakuuksien puutteesta (emt.). 2010-luvulla näiden yritysten tilanne on muuttunut merkittävästi, sillä erilaiset joukkorahoituksen muodot ovat yleistyneet nopeasti. On silti huomattava, että alhaisen korkotason tuomasta edullisen rahoituksen saatavuudesta huolimatta yritykset kokonaisuudessaan eivät ole laajentaneet rahoituksella tuotannollisia investointeja - yritysten nettoinvestoinnit olivat 2010-luvulla keskimäärin nollassa. 
Työmarkkinat ja työmarkkinapolitiikka. Työn laadullinen muutos on Suomessa pitkäikäinen keskustelunaihe. 2010-luvulla työssä nähtiin merkittäviä muutoksia. Tilastot osoittavat, että Suomen talouden painopisteen siirtyminen palveluihin näkyi työmarkkinoilla sektoritason siirtyminä. Työpaikat lisääntyivät 2010-luvun aikana ennen kaikkea liike-elämän palveluissa, sosiaali- ja terveyspalveluissa sekä eräissä muissa palveluissa, kuten viestintä-, ravitsemus- ja viihdepalveluissa ja koulutuksessa. Muista aloista lähinnä rakennusalalla tapahtui työpaikkojen lisääntymistä. Samat tilastot näyttävät, että vaikka työvoima-aste pysyi pitkälti ennallaan 2010-luvun, työllisyysaste nousi ja työttömyysaste laski 2010-luvulla jokseenkin merkittävästi. Suomen ja Viron työmarkkinoiden integraatio näyttää esimerkkien valossa vahvistuneen. Työelämän laadullisen muutoksen osalta erityisesti prekarisaation eli työelämän yleisen epävarmistumisen ilmiö herätti paljon keskustelua tutkijoiden parissa (Harju 2017). 2010-luvulla myös työn organisoinnissa tapahtui merkittävä muutos, kun alustatalous alkoi haastaa markkinapohjaista työn järjestämistä ja työntekijän yhteiskunnallista asemaa (Kenney ja Zysman 2019; Suomessa esim. Mattila 2019). Tiivistetysti ilmaistuna 2010-luvulla Suomessa työtä luonnehti palvelullistuminen, vähittäinen lisääntyminen ja tulevaisuuden kehityskulkujen monenlainen epävarmistuminen.

Suurimmat muutokset nähtiin kuitenkin työtä ohjaavissa mekanismeissa. Työmarkkinapolitiikassa tapahtui radikaaleja muutoksia (esim. JonkerHoffrén 2020; Wuokko ym. 2020). 2010-luvun alussa näytti siltä, että keskitetyn sopimisen aika oli Suomessa ohi ja Suomi oli siirtymässä muiden Pohjoismaiden tavoin kohti sektori- tai yrityskohtaista sopimista sekä näiden keskitettyä koordinaatiota (Andersen ym. 2015; Kiander ym. 2011). Vuosikymmenen puolivälissä nähtiin hetkellisesti yllättävä suunnanmuutos, kun kuolevaksi väitetyn järjestelmän yhteydessä tehtiin uusi keskitetty kolmikantainen sopimus eli Sipilän hallituksen kilpailukykysopimus (Kaitila 2019). Suunnanmuutos osoittautui lyhytaikaiseksi. Sopimuksen keskeisistä sisällöistä on sittemmin luovuttu ja trendi kohti koordinoitua hajautettua sopimista jatkunut (Jonker-Hoffrén 2019). Elinkeinoelämän keskusliitto (EK) on poistanut itseltään mahdollisuuden osallistua keskitettyyn sopimiseen.

Hypoteesina voidaan esittää, että kotimaista työmarkkinapolitiikkaa vaivaa eräänlainen kohtaamattomuus, joka heikentää Suomen talouden koordinaatiokykyä. Talouden rakennemuutoksen hallitsemiseksi sopimista tarvittaisiin 
ennen kaikkea sektoritasolla eli sektoreiden sisällä ja välillä, mistä edellinen vaatii kykyä täydentävään paikalliseen sopimiseen ja jälkimmäinen keskitettyä koordinaatiota (Jonker-Hoffrén 2020). Neuvottelukulttuurin koordinaation niin sanottu Suomen malli eli sopimisen ankkuroiminen vientiteollisuuden palkkaratkaisuihin ei edistä sektoreiden erilaisten lähtökohtien huomiointia. Ammattiliitot ovat pyrkineet johdonmukaisesti vahvistamaan koordinaatioja neuvottelukapasiteettiaan sektoritasolla, mutta eivät pysty käyttämään sitä niin kutsutun kompetenssiansan takia (ks. Jonker-Hoffrén 2020). Työnantajien parissa kyky keskitettyyn koordinaatioon on heikentynyt sekä halu siirtää kaikkea sopimista paikallistasolle lisääntynyt. Tärkeimpänä tapauksena voidaan pitää Metsäteollisuutta, joka ensin irtautui EK:sta (Aitonurmi 2019) ja myöhemmin vuonna 2020 päätti luopua toimialakohtaisesta sopimisesta ja siirtyä mahdollisimman paikalliseen sopimiseen. On epäselvää, miten laajasti kotimaisilla yrityksillä on kykyä ja osaamista sopia paikallisesti talouden kannalta merkittävistä asioista (Kärrylä 2020). Aiempi tutkimus osoittaa, että myös ammattiliittojen kyky sopia paikallisesti on vaihdellut (Sippola 2012).

Innovaatiojärjestelmä. 2000-luvun ensimmäisellä vuosikymmenellä Suomessa voitiin puhua kansallisella tasolla voimiensa tunnossa olevasta innovaatiojärjestelmästä. Järjestelmää luonnehti suora innovaatiotoiminta, jossa teknologiaa suunniteltiin, kehitystoimintaa toteutettiin ja osaamista jaettiin laajassa yhteistyössä eri toimijoiden välillä. Järjestelmä oli rakennettu laajojen yritystoimintaa, tutkimusta ja koulutusta yhdistäviin toiminnan muotojen, kuten strategisen huippuosaamisen keskittymien, Tekesin rahoittamien julkisyksityisten innovaatiohankkeiden ja Nokian ympärille rakennetun teknologiaklusterin varaan (Laasonen ym. 2020; Lemola 2020).

2010-luvun aikana innovaatiopolitiikassa tapahtui merkittävä suunnanmuutos. Kansallisesta innovaatiojärjestelmästä tuli politiikassa ennemmin ongelma itsessään kuin ratkaisu talouden ongelmiin (Alaja ja Sorsa 2020). Siinä missä Tekesin entinen johtaja on kuvannut muutoksia siirtymäksi 20 vuotta taaksepäin, ovat toiset nähneet politiikan muutoksen myös innovaatiopolitiikan laajentumisena ja syventymisenä (Laasonen ym. 2020). Kotimainen panostus TKI-toimintaan joka tapauksessa vähentyi 2010-luvulla niin euromääräisesti, suhteessa bruttokansantuotteeseen kuin suhteessa kilpailijamaihinkin. 2010-luvun aikana varsinkin julkisen sektorin rooli muuttui merkittävästi innovaatiotoiminnassa. Yhteistyötä suoraan edistävien toimien 
sijaan valtio on keskittynyt markkinavetoisen innovaatiotoiminnan mahdollistamiseen. Tiivistetysti "julkisten innovaatiopalveluiden verkosto kaventui, kansainvälistyi, tiivistyi tietokeskittymiin [knowledge hub] sekä kohdistui kasvuun ja innovaatio-orientoituneeseen startup-yrittäjyyteen" (Laasonen ym. 2020, suomennos VS).

2010-luvun kehityskulkujen seurauksena kotimainen innovaatiopolitiikka on pitkälti "hajaannuksen tilassa" (Laasonen ym. 2020). Samaa voidaan sanoa talouden koordinaatiotapojen osalta. Yhtäältä uusi, toimialakohtaisia, alueellisia ja/tai jopa arvoketjukohtaisia TKI-ekosysteemejä korostava lähestymistapa sopii koordinoimaan uutta tilannetta, jossa pienemmät liike-elämän palveluita tarjoavat yritykset ovat nousseet merkittäviksi. Omaksuttu koordinoinnin tapa ei siihen kuitenkaan sovi. Monet näistä yrityksistä ovat nopeasti muuttuvilla markkinoilla operoivia palveluyrityksiä, joiden TKI-kapasiteetin kehittäminen ja levittäminen on riippuvaista laajoista, vakaista ja pitkäaikaisista yhteistyösuhteista. Näitä eivät markkinavetoisen koordinaation rakenteet kilpailtuine ja lyhytaikaisine rahoituksineen ja tuotteistamisfokuksineen tarjoa. Toisaalta on selvää, ettei myöskään Nokian kaltaisiin kansallisesti neuvoteltuihin klustereihin ole mahdollisuuksia siirtyä intressien ja arvoketjutyyppien suhteen polarisoituneessa liiketoimintajärjestelmässä.

Makrotaloudellinen regiimi. Suomen makrotaloudellisen regiimin suurimmat muutokset koettiin 1990- ja 2000-luvuilla. Koska Suomi on Euroopan unionin ja rahaliiton jäsenmaa, on sen makrotaloudellinen regiimi pitkälti sidottu eurooppalaisen regiimin kehitykseen. Kyseisessä regiimissä finanssipolitiikka ja yleisemmin valtion rahoitusjärjestelmä on rajattu, rahapolitiikka ja markkinoiden sääntely kaikille yhteistä sekä yritysten suora tukeminen kiellettyä. Kansallisella tasolla voidaan päättää laajamittaisesti lähinnä uudelleenjaosta verotuksen ja sosiaalipolitiikkaan liittyvien tulonsiirtojen kautta. 2010-luvun eurooppalaista makrotalousregiimiä on luonnehtinut kiristyvä finanssipolitiikan kontrolli ja rajoittaminen sekä suhdannepolitiikan ylläpito entistä enemmän rahoitusmarkkinoiden välityksellä Euroopan keskuspankin osto-ohjelmien myötä (ks. Johnston ja Regan 2018).

2010-luvulle tultaessa Suomi edusti Euroopan sisäisessä variaatiossa pääasiallisesti "vientivetoista" eli ulkomaiseen kysyntään ja/tai ulkomailta voittojen kotiuttamiseen perustuvaa kasvumallia. Siinä missä Suomen talous oli vielä jokseenkin vientivetoinen 2000-luvun ensimmäisellä vuosikymmenellä, 
kääntyi se kotimaisesta kysynnästä riippuvaiseksi 2010-luvun aikana (Hein ja Martschin 2020). Vientiteollisuuden lasku, erityisesti Nokian romahdus ja Metsäteollisuuden tuotteiden vientikysynnän heikentyminen, sekä palveluviennin arvonlisäyksen realisoituminen arvoketjuissa ulkomailla ovat merkittävä osa tätä muutosta. Suomen makrotaloudellisesta regiimistä oli koronakriisin alla siten tullut entistä enemmän kotimaisesta kysynnästä riippuvaista. Riippuvuutta kotimaisesta taloudesta lisää finansoituneen talouden olosuhteissa myös se, että kotimainen varallisuus on pitkälti kiinni asunnoissa tai kotimaisissa sijoituskohteissa.

Hypoteesina voidaan esittää, että Suomen makrotaloudellisen regiimin koordinointikyky on heikentynyt. Euroalueen instituutiot heikentävät kotimaisesta kysynnästä riippuvaisen kasvumallin toteuttamismahdollisuuksia erityisesti finanssipolitiikan osalta (Johnston ja Regan 2018). Toisaalta myös kotimaisessa talouspolitiikassa on myös keskitytty viennin edistämiseen jopa kotimaista kysyntää heikentävillä keinoilla (Kaitila 2019). Kotimaisen investointiasteen stagnaatio tai "investointilama" antaa aihetta yleiseen skeptisyyteen kysynnän ylläpitoon ongelmatilanteissa. Suomen laajat tulonsiirrot ja automaattiset vakauttajat auttavat periaatteessa ylläpitämään laajamittaista kulutuskysyntää Etelä-Euroopan maita paremmin. On kuitenkin huomattava, että Suomen sosiaalipoliittiset tulonsiirrot eivät ole eurooppalaisessa vertailussa olleet 2000-luvulla enää erityisen uudelleenjakavia tai vakauttavia (Jahn 2018).

\section{Johtopäätöksiä ja keskustelua}

Miltä Suomen poliittinen talous sitten näyttää kokonaisuutena? Jos Suomea oli vaikea luokitella kapitalismin variaatioiden ideaalityyppeihin 2000-luvun alussa tuolloisten typologioiden valossa, ei se ole muuttunut yhtään helpommaksi vuonna 2020 nykyisten typologioiden valossa, jossa instituutioiden toiminta otetaan entistä vakavammin (Jackson ja Deeg 2019).

Suomen taloutta ajoivat 1980-2000-luvun koordinoidun markkinatalouden piirteiden tuottamat menestystekijät, kuten korkea tuottavuus ja inkrementaalinen innovatiivisuus vientiteollisuudessa. Vakaa yhtiöhallinto mahdollisti strategisen toiminnan, keskitetty sopiminen palkkamaltin ja osaamisen kehittämisen sekä innovaatiojärjestelmä laajoja arvoketjuja rakentavan yhteistyön. 
Kuten teoria antaa olettaa (Witt ja Jackson 2016), tietynlainen hybridisaatio eli neuvottelun osittainen korvaaminen markkinamekanismeilla vahvisti kotimaista kilpailukykyä entisestään - ohjauksen markkinavetoistuminen edisti vientiyritysten kulukuria ja innovaatiojärjestelmän markkinoistaminen palveluvientiä. Tämä kuva ideaalisesta korkean osaamisen ja teknologian investointiympäristöstä sekä kansainvälisiin markkinoihin integroituneesta vienti-ihmeestä näkyi pitkään myös Suomen maabrändissä (Frig ja Sorsa 2018).

Suomen poliittisen talouden voidaan kuitenkin tulkita päätyneen tilaan, jossa menestystarinan pohjana oleva koordinoitu markkinatalous on pitkälti kadonnut muiden elementtien "alta”. Työmarkkinajärjestelmän ja innovaatiojärjestelmän muutokset ehdottavat, ettei Suomea välttämättä voida enää lukea kovinkaan luontevasti koordinoiduksi markkinataloudeksi minkään yksittäisen osa-alueen kautta. Yhtiöhallinnon ja rahoitusjärjestelmän sekä makrotaloudellisen regiimin osalta Suomi on näyttäytynyt jo kahden vuosikymmenen ajan pikemminkin liberaalin markkinatalouden ja riippuvaisen markkinatalouden koordinaation piirteitä samanaikaisesti hyödyntävältä hybridiltä. Jäljelle jäänyt yhdistelmä liberaalia ja riippuvaista markkinataloutta, jossa on myös muutamia koordinoidun markkinatalouden piirteitä, palvelee enemmän ulkomaille arvonlisää kanavoivien kansainvälisten arvoketjujen toimintaa kuin tuottaa systemaattisesti uusia arvoketjuja ja korkean lisäarvon innovaatioita.

Tilanteeseen liittyy kuitenkin monia jännitteitä ja epäsuhtia, joiden valossa puhe hybridistä voi ylipäätään olla liioiteltua. Vaikka riippuvuus kotimaisesta kysynnästä ja palveluista on kasvanut, makrotalouden regiimiä ohjaavat edelleen vientivetoisen tuotannollisen kasvun ideat. Innovaatiojärjestelmän ideat ovat lupaavia uudessa taloudellisessa rakenteessa, mutta markkinaperusteiset instituutiot eivät tue niiden toteuttamista. Työmarkkinapolitiikassa talouden rakennemuutoksen hallinta vaatisi tarvittaessa koordinaatiota ja neuvottelemista niillä tasoilla, joilla siihen on heikoimmin kykyä, halua ja mahdollisesti myös osaamista. Mikäli talouden ohjaaminen tapahtuu vain yritysten kautta, tekee liiketoimintajärjestelmän polarisaatio tästä erittäin haastavaa. Yritystoiminnan laaja-alainen ohjaaminen vaatisi ankkuriomistajuuden lisäämistä ja merkittävää panostusta neuvottelevaan omistajaohjaukseen. 
Komplementaarisuuden astetta täytyisi toki mitata selkeämmin ja koordinaatiokykyä arvioida instituutiokohtaisemmin, jotta voitaisiin sanoa, missä määrin nämä jännitteet ja epäsuhdat vaikuttavat kotimaisen talouden toimintaan. Arvioisin kehityksen suunnan olevan kuitenkin tämä: talouden koordinaatio on muuttunut vähemmän vaikuttavaksi ja taloudellista toimintaa ohjaavien instituutioiden väliset synergiat eli komplementaarisuudet ovat jossain määrin heikentyneet 2010-luvulla.

Mikäli arvio pitää paikkaansa, liittyy COVID-19-kriisin taloudellisten seurauksien hallintaan tiettyjä epävarmuuksia. Suomi on pärjännyt taloudellisilla mittareilla erinomaisesti kriisin hallinnassa. Vuonna 2020 kriisin taloudelliset vaikutukset ovat olleet bruttokansantuotteella mitattuna muutaman prosentin laskun luokkaa, kun useissa maissa lasku on ollut moninkertaista. Teollisuuden tilauskanta on heikentynyt merkittävästi, mutta suurimmat kriisin kärsijät ovat silti yksityisiä, suhteellisen pieniä palvelualojen yrityksiä. Työttömyys ei ole radikaalisti lisääntynyt, eikä konkurssiaaltoja vielä vuonna 2020 näkynyt. Syynä onnistumisiin on se, että valtio on onnistunut oman historiansa valossa poikkeuksellisesti harjoittamaan riittävän kattavaa ja aktiivista suhdannepolitiikkaa. Poikkeustilanne on ylitetty hyvin pragmaattisesti pitämällä talouden pyörät pyörimässä runsaalla julkisella ja yksityisellä velalla.

Tämän artikkelin analyysi Suomen poliittisen talouden tilasta koronakriisin alla nostaa kaksi huolenaihetta koronakriisin taloudellisten jälkiseurausten hoitoa koskien. Ensinnäkin korkea riippuvuus kotimaisesta kysynnästä ja yksityisistä palveluista vaativat aktiiviselta finanssipolitiikalta sellaista pitkäjänteisyyttä, johon Suomessa ei ole ollut historiallisesti malttia. Kaikkien palvelualojen yritysten toiminta ei luultavasti tule palaamaan ennalleen, eivätkä velkaantuneet yritykset pysty saavuttamaan samaa voittoastetta kuin aiemmin. Konkursseilta ei voida välttyä, eikä investointiaste tule helposti nousemaan. Jotta tilanne ei kääntyisi pitkäaikaisemmaksi lamaksi, täytyisi kokonaiskysyntää hallita finanssipolitiikalla vielä pitkään. Viranomaisten huoli kestävyysvajeen kasvattamisesta ja eräiden asiantuntijoiden huolet teollisuuden kilpailukyvystä osoittavat, että riski aktiivisen suhdannepolitiikan liian aikaisesta lopettamisesta on merkittävä.

Toiseksi on syytä olla huolissaan Suomen talouden uudistumiskyvystä. Suomi nousi 1990-luvun lamasta pitkälti uusien teknologioiden, pitkäjänteisen TKI-toiminnan ja liiketoimintajärjestelmän uudelleen suuntaamisen ansiosta. 
Kuten edellä totesin, 2020-luvun alun poliittisen talouden olosuhteissa lienee turha odottaa uutta Nokiaa. Suomen talouden ekologisen kestämättömyyden johdosta on kuitenkin ilmeistä, että suuruusluokaltaan ja nopeudeltaan Nokian kasvuun verrattavaa ekologisen jälleenrakennuksen ohjelmaa tarvittaisiin nyt kipeästi. Edellä kuvatun heikentyneen koordinaatiokyvyn myötä tämän suuruusluokan suunnanmuutosten toteuttamiseen ei välttämättä ole riittäviä institutionaalisia edellytyksiä. Politiikassa toistaiseksi vallitsevat ideat ja liiketoimintaintressien polarisaatio eivät nekään tue suunnanmuutoksen aloittamista.

Mikäli metsäteollisuuden tuotteiden kysyntä ja sitä kautta suuryritysten asema heikkenee Suomessa edelleen, on Suomen talous pitkälti suhteellisten pienten palveluyritysten varassa. Tällaisten yritysten kasvattaminen ei onnistu suoralla vienninedistämisellä tai "rakenteellisilla uudistuksilla", vaan radikaalia muutosta tuottavien arvoketjujen vähittäisellä rakentamisella. Tämä vaatii erittäin pitkäjänteistä TKI-toimintaa, yhteistyötä edistävän ekosysteemin rakentamista, aktiivisesti rakennemuutosta tukevaa makrotalouspolitiikkaa

sekä kehityskuluista riippuen mahdollisesti myös rahoitus- ja työmarkkinoiden hallittua uudelleensuuntaamista nousevia arvoketjuja tukeviksi.

\section{Lähteet}

Aitonurmi, Joonas. 2019. Työnantajajärjestöjen poliittinen edustuksellisuus: tapaustutkimuksena Metsäteollisuus ry. Pro gradu -tutkielma. Valtiotieteellinen tiedekunta, Helsingin yliopisto.

Alaja, Antti ja Sorsa, Ville-Pekka. 2020. The evolution of the national innovation system as programmatic policy idea in Finland. Science and Public Policy, advance access. https://doi.org/10.1093/scipol/scaa045

Andersen, Søren Kaj ym. 2015. Changes in wage policy and collective bargaining in the Nordic countries-comparison of Denmark, Finland, Norway and Sweden. Teoksessa Guy van Gyes ja Thorsten Schulten (toim.) Wage bargaining under the new European Economic Governance. Bryssel: European Trade Union Institute, 139-168. 
Browning, Gary ja Kilmister, Andrew. 2006. Critical and Post-Critical Political Economy. Palgrave Macmillan UK.

Campbell, John L. ja Pedersen, Ove K. 2014. The National Origins of Policy Ideas: Knowledge Regimes in the United States, France, Germany, and Denmark. Princeton: Princeton University Press.

Cohen, Benjamin (toim.) 2017. International Political Economy. Abindgon: Routledge.

Elomäki, Anna, Mustosmäki, Armi, ja Koskinen Sandberg, Paula. 2020. The Sidelining of Gender Equality in a Corporatist and Knowledge-Oriented Regime: The Case of Failed Family Leave Reform in Finland. Critical Social Policy, advance access. https://doi.org/10.1177\%2F0261018320947060 Finér, Lauri ja Ylönen, Matti. 2017. Tax-Driven Wealth Chains: A Multiple Case Study of Tax Avoidance in the Finnish Mining Sector. Critical Perspectives on Accounting, 48, 53-81.

Frig, Meri, ja Sorsa, Ville-Pekka. 2020. Nation Branding as Sustainability Governance: A Comparative Case Analysis. Business \& Society 59:6, 1151-80. Hall, Peter A. ja Soskice, David W. 2001. An Introduction to Varieties of Capitalism. Teoksessa Peter A. Hall ja David W. Soskice (toim.) Varieties of Capitalism. New York: Oxford University Press, 1-70.

Hall, Peter A. ja Thelen, Kathleen. 2009. Institutional change in varieties of capitalism. Socio-Economic Review, 7(1), 7-34.

Harju, Sanna. 2017. Prekarisaatio: katsaus prekarisaatioilmiöön sekä analyysi suomalaisesta prekaaridiskurssista 2000-luvulla. Pro gradu -tutkielma. Yhteiskuntatieteiden tiedekunta, Tampereen yliopisto.

Harjuniemi, Timo. 2020. Asiantuntijoita vai asiansa ajajia? Suomalaisten toimittajien näkemyksiä talouspolitiikan asiantuntijuudesta. Talousviisaat julkisuuden vaikuttajina -hankkeen loppuraportti. Helsinki: Unigrafia. https:// www.hssaatio.fi/wp-content/uploads/2020/12/Asiantuntijoita-vai-asiansaajajia.pdf [Luettu 21.12.2020]

Hay, Colin. 2004. Ideas, interests and institutions in the comparative political economy of great transformations. Review of International Political Economy, 11:1, 204-226.

Hein, Eckhard ja Martschin, Judith. 2020. The Eurozone in Crisis - A Kaleckian Macroeconomic Regime and Policy Perspective. Review of Political Economy, 32:4, 563-588. 
Ihatsu, Jan. 2020. Valtioneuvoston ytimen koordinaatiotoimien kehitys Suomessa 2011-2019. Pro gradu -tutkielma. Valtiotieteellinen tiedekunta, Helsingin yliopisto.

Jackson, Gregory ja Deeg, Richard. 2019. Comparing Capitalisms and Taking Institutional Context Seriously. Journal of International Business Studies, 50:1, 4-19.

Jahn, Detlef. 2018. Distribution Regimes and Redistribution Effects during Retrenchment and Crisis: A Cui Bono Analysis of Unemployment Replacement Rates of Various Income Categories in 31 Welfare States. Journal of European Social Policy, 28:5, 433-451.

Jakobsson, Ulf, ja Korkeamäki, Timo. 2015. Ownership and corporate governance in Finland: A review of development trends. Nordic Journal of Business, 64:4, 232-248.

Johnston, Alison, ja Regan, Aidan. 2018. Introduction: Is the European Union Capable of Integrating Diverse Models of Capitalism? New Political Economy, 23:2, 145-59.

Jonker-Hoffrén, Paul. 2019. Finland: goodbye centralised bargaining? The emergence of a new industrial bargaining regime. Teoksessa Torsten Müller, Kurt Vandaele ja Jeremy Waddington (toim.) Collective bargaining in Europe: towards an endgame. Bryssel: ETUI, 197-216.

Jonker-Hoffrén, Paul. 2020. Decentralisation in the context of competitiveness discourse: The Finnish labour market relations system since 2008. Teoksessa Nicol Foulkes Savinetti ja Aart-Jan Riekhoff (toim.) Shaping and re-shaping the boundaries of working life. Tampere: Tampere University Press, 159-180.

Kaitila, Joel. 2019. From Innovation to Labour Costs: Change of Emphasis in Finnish Competitiveness Policy Ideas after the Eurocrisis. Competition $\mathcal{E}$ Change, 23:1, 47-70.

Kantola, Anu, ja Kananen, Johannes. 2013. Seize the Moment: Financial Crisis and the Making of the Finnish Competition State. New Political Economy, 18:6, 811-826.

Kenney, Martin, ja John Zysman. 2019. Work and Value Creation in the Platform Economy. Teoksessa Steve P. Vallas ja Anne Kovalainen (toim.) Work and Labor in the Digital Age. Emerald Publishing Limited, 13-41. 
Kiander, Jaakko, Sauramo, Pekka ja Tanninen, Hannu. 2011. Finnish Incomes Policy as Corporatist Political Exchange: Development of Social Capital and the Social Wage. Transfer: European Review of Labour and Research, 17:4, 515-531.

Kotilainen, Konsta ja Patomäki, Heikki. 2020. Towards a Helsinki Approach to Global Political Economy: Integrating Pluralist Economic Theorisation and Critical IPE. Helsinki Global Political Economy Working Paper. Helsinki: Helsingin yliopisto. https://www.helsinki.fi/en/networks/global-politicaleconomy/working-paper-12020 [Luettu 21.12.2020]

Kristensen, Peer Hull ja Lilja, Kari (toim.) 2011. Nordic Capitalisms and Globalization: New Forms of Economic Organization and Welfare Institutions. Oxford, New York: Oxford University Press.

Kärrylä, Ilkka. 2020. Mitä paikallinen sopiminen on ja mitä sen haluttaisiin olevan? Politiikasta.fi. https://researchportal.helsinki.fi/en/publications/ mit\%C3\%A4-paikallinen-sopiminen-on-ja-mit\%C3\%A4-sen-haluttaisiinolevan [Luettu 21.12.2020]

Laasonen, Valtteri, Kolehmainen, Jari ja Sotarauta, Markku. 2020. The complexity of contemporary innovation policy and its governance in Finland. Innovation: The European Journal of Social Science Research, advance access. https://doi.org/10.1080/13511610.2020.1842176

Lemola, Tarmo. 2020. Kohti uutta tutkimus- ja innovaatiopolitiikkaa: Suomen tiede-, teknologia- ja innovaatiopolitiikan kehityskaari 1960-luvulta 2020-luvulle. Tampere: Vastapaino.

Levine, David P. 2014. Normative Political Economy: Subjective Freedom, the Market and the State. Routledge.

Lillqvist, Ella, Kavonius, Ilja Kristian ja Pantzar, Mika. 2020. "Velkakello tikittää": Julkisyhteisöjen velka suomalaisessa mielikuvastossa ja tilastoissa 2000-2020. Kansantaloudellinen Aikakauskirja, 116:4, 581-607.

Lindén, Michael. 2016. Arbetspensionsreformförhandlingarnas politiska närhistoria: Processbeskrivning och jämförande analys av arbetspensionsreformprocesserna i Finland på 2000-talet ur ett diskursiv institutionellt perspektiv. Pro gradu -tutkielma. Valtiotieteellinen tiedekunta, Helsingin yliopisto.

Mattila, Maija. 2019. Työ ja työntekijöiden oikeudet alustataloudessa. Ongelmista ratkaisuihin. Helsinki: Kalevi Sorsa -säätiö. 
Moen, Eli ja Lilja, Kari. 2005. Change in coordinated market economies: The case of Nokia and Finland. Teoksessa Glenn Morgan, Richard Whitley ja Eli Moen (toim.) Changing capitalisms? Internationalism, Institutional Change, and Systems of Economic Organization. New York: Oxford University Press, 352-382.

Morgan, Glenn. 2014. Financialization and the Multinational Corporation. Transfer: European Review of Labour and Research, 20:2, 183-197.

Mosco, Vincent. 2009. The Political Economy of Communication. 2. painos. Lontoo: SAGE Publications Ltd.

Mähönen, Jukka T. 2013. Finland. Teoksessa Andreas M. Fleckner ja Klaus J. Hopt (toim.) Comparative Corporate Governance: A Functional and International Analysis. Cambridge: Cambridge University Press, 393-443.

Nölke, Andreas. 2016. Economic causes of the Eurozone crisis: the analytical contribution of Comparative Capitalism. Socio-Economic Review, 14:1, 141-61.

Nölke, Andreas. 2019. Comparative Capitalism. Teoksessa Timothy M. Shaw, Laura C. Mahrenbach, Renu Modi ja Xu Yi-chong (toim.) The Palgrave Handbook of Contemporary International Political Economy. Lontoo: Palgrave Macmillan UK, 135-151.

Nölke, Andreas, ja Arjan Vliegenthart. 2009. Enlarging the Varieties of Capitalism: The Emergence of Dependent Market Economies in East Central Europe. World Politics, 61:4, 670-702.

Oinas, Päivi. 2005. Finland: A success story? European Planning Studies, 13:8, 1227-1244.

Phelps, Edmund S. 1985. Political Economy: An Introductory Text. New York: W. W. Norton \& Company.

Sippola, Markku. 2012. Local Bargaining and Codetermination: Finnish Experience in Comparative Perspective. European Journal of Industrial Relations, 18:1, 53-69.

Skurnik, Samuli. 2005. Suomalaisen talousmallin murros: suljetusta sääntel ytaloudesta kaksinapaiseen globaalitalouteen. Helsinki: Tammi.

Sorsa, Ville-Pekka. 2013. Mitä on poliittinen talous ja miksi sen tutkimusta tulee edistää?” Poliittinen talous, 1:1, 66-80.

Sorsa, Ville-Pekka. 2014a. Kestävyysvajeen politiikkaidean kritiikki. Politiikka, 56:2, 132-42. 
Sorsa, Ville-Pekka. 2014b. Suomalaisen kilpailuvaltion hallintastrategia: koordinaatiota ilman synergioita? Tiede \& edistys, 39:3, 195-213.

Sorsa, Ville-Pekka. 2017. Pääkirjoitus: Millaista tutkimustietoa päätöksentekoon? Poliittinen talous, 5:1, 75-89.

Sorsa, Ville-Pekka. 2019a. Talouden rajallisuuden ja kontingenssin äärellä. Sosiologia, 56:2, 189-191.

Sorsa, Ville-Pekka. 2019b. Tieteellisen artikkelin kontribuutio. Poliittinen talous, 6-7. https://journal.fi/poliittinentalous/issue/view/6624

Sorsa, Ville-Pekka, ja Teppo Eskelinen. 2018. Taloustieteellinen asiantuntemus teknotaloudellisessa kapitalismissa. Politiikka, 60:1, 79-88.

Stilwell, Frank. 2011. Political Economy: The Contest of Economic Ideas, 3rd Edition: Political Economy: The Contest of Economic Ideas. Kolmas painos. Oxford, New York: Oxford University Press.

Suomen Pankki. 2015. Yritysrahoituskysely 2015. https://helda.helsinki.fi/bof/ handle/123456789/13947 [Luettu 21.12.2020]

Tuominen, Tomi. 2015. Budjettikurisopimus - kestävään talouteen pakottaminen oikeuden keinoin. Poliittinen talous, 3:1, 29-47.

Tuominen, Tomi. 2019. Eurooppalainen vakauttajavaltio Suomessa. Poliittinen talous, 6-7. https://journal.fi/poliittinentalous/article/view/96121.

Witt, Michael A, Kabbach de Castro, Luiz Ricardo, Amaeshi, Kenneth, Mahroum, Sami, Bohle, Dorothee ja Sáez, Lawrence. 2018. Mapping the business systems of 61 major economies: a taxonomy and implications for varieties of capitalism and business systems research. Socio-Economic Review, 16:1, 5-38.

Witt, Michael A. ja Jackson, Gregory. 2016. Varieties of Capitalism and Institutional Comparative Advantage: A Test and Reinterpretation. Journal of International Business Studies, 47:7, 778-806.

Wuokko, Maiju, Jensen-Eriksen, Niklas, Tala, Henrik, Kuorelahti, Elina ja Sahari, Aaro. 2020. Loputtomat kihlajaiset: Yritykset ja kolmikantakorporatismi Suomessa 1940-2020. Helsinki: Siltala.

Ylönen, Matti, Jaakkola, Jussi, Saari, Leevi ja Hiilamo, Heikki. 2020. Näyttöperusteisuus ja yritysten verotus: ekonomismin nousu suomalaisen yhteisöveropolitiikan tiedontuotannossa. Poliittinen talous, 8. https://journal.fi/ poliittinentalous/article/view/96159 
Ylönen, Matti ja Kuusela, Hanna. 2019. Consultocracy and Its Discontents: A Critical Typology and a Call for a Research Agenda. Governance, 32:2, 241-258.

Ylöstalo, Hanna. 2020a. Depoliticisation and Repoliticisation of Feminist Knowledge in a Nordic Knowledge Regime: The Case of Gender Budgeting in Finland. NORA - Nordic Journal of Feminist and Gender Research, 28:2, 126-139.

Ylöstalo, Hanna. 2020b. The role of scientific knowledge in dealing with complex policy problems under conditions of uncertainty. Policy E Politics, 48:2, 259-276. 